\title{
Determining the Effectiveness of Using Remote Sensing Indices to Deriving Sabkhas in Wadi An- Natrun Depression - Egypt
}

\author{
By \\ Dr. Islam Saber Amin \\ Associate Professor of Geomorphology \\ and Geographical Information System \\ Faculty of Arts, Banha University.
}

DOI: 10.21608/jfpsu.2021.90727.1124 
Determining the Effectiveness of Using Remote... Dr. Islam Saber Amin

\section{Determining the Effectiveness of Using Remote Sensing Indices to Deriving Sabkhas in Wadi An-Natrun Depression - Egypt}

\section{Abstract}

The floor of Wadi An-Natrun Depression has a high level of salinity and occupies by a shallow salt lakes, which are characteristic geomorphologic landforms. In general, Wadi An-Natrun Depression is characterized by very arid climate. The geological formations of Wadi An-Natrun Depression range from lower Miocene, lower Pliocene and Quaternary deposits. This study attempts to determine the effectiveness of using remote sensing indicators in deducing sabkhas in the Wadi El-Natrun depression utilizing Landsat 8 OLI satellite images based on field data of laboratory analyzes of sabkhas soil samples collected through the field study. To achieve this, linear and multiple regression models were applied between soil salinity and electrical conductivity (ECe) on the one hand and remote sensing indices on the other hand, where the NDSI index had the highest correlation coefficient of 0.872 . This was followed by the derivation of the Enhanced soil salinity index from (NIR), (SWIR) 2 and the NDVI index, which had higher correlation than NDSI with electrical conductivity (ECe) of 0.918 .

keywords: Remote sensing. salinity indices, Wadi An-Natrun, depression, sabkha, salt lakes.

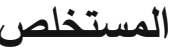

يتميز قاع منخفض وادي النطرون بمستوى عالٍ من الملوحة وتحتله بحيرات ملحية

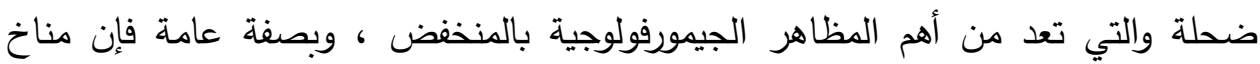
منخفض وادي النطرون يتسم بثدة الجفاف ، تتراوح التكوينات الجيولوجية بالمنخف بين الميوسين الأسفل والبليوسين الاسفل بالإضافة إلي رواسب البليستوسين والحديث ـ ـ تحاول هذه الدراسة تحديد فاعلية استخدام مؤشرات الاستشعار عن بعد في استتباط السبخات

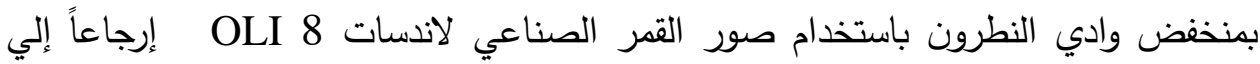

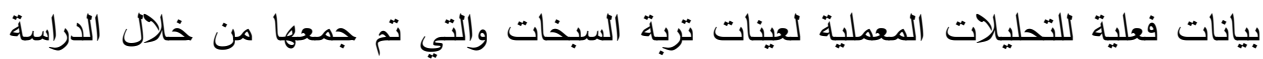


الميدانية ـ ولتحقيق ذلك ، تم تطبيق نماذج الانحدار الخطي والمتعدد بين ملوحة التربة والتوصيل الكهربائي (ECe) من ناحية ومؤشرات الاستشعار عن بعد من ناحية اخري ، حيث

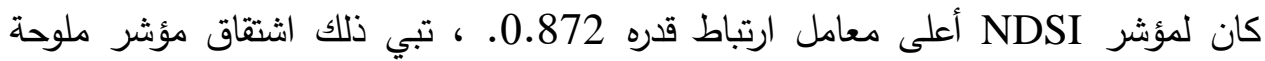

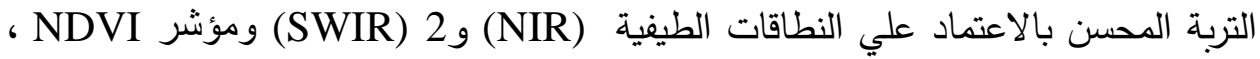

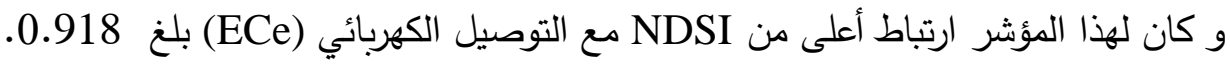
الكلمات المفتاحية: الاستشعار عن بعد، مؤشرات الملوحة، وادي النطرون.

\section{Introduction}

Sabkha is an Arabic term refers to the salt marsh. Sabkhas are divided into two types, continental and coastal. The sabkhas are dynamic geomorphological features that is characterized by the continuous change in area according to the prevailing climatic conditions, whether these changes are seasonal changes or long-term changes. This has led to difficulty of completely distinguish its boundaries, especially during field work. Therefore, satellite images are the best solution for identifying, especially with the use of salinity indices and the possibility of enhancing these indices until we reach the optimal conclusion of the boundaries of sabkhas.

The current study focuses on studying the different methods of distinguishing sabkha boundaries from satellite images, using the indices of automatic deduction of sabkhas, with the possibility of enhancing these indices, applying on Wadi An-Natrun Depression sabkhas in Egypt.

\section{1- Study Area}

Wadi An-Natrun Depression located in the western part of the Western Egyptian Desert, relatively closes to the Nile Delta . It lies between latitude of $30^{\circ} 15^{\prime} 29^{\prime \prime}, 30^{\circ} 33^{\prime} 23^{\prime \prime} \mathrm{N}$ and a longitude of $29^{\circ} 59^{\prime} 19^{\prime \prime}, \quad 30^{\circ} 30^{\prime} 50^{\prime \prime} \mathrm{E}$ approximately $130 \mathrm{~km}$ northwest of Cairo. Wadi An-Natrun Depression is a closed depression, as it is bounded on all sides by escarpments of varying morphological characteristics, that gradually slope towards its floor, the two major 
escarpments are : the northeastern escarpment with a height of 40 $\mathrm{m}$ above sea level and the southwestern escarpment which rises to about $180 \mathrm{~m}$ above sea level. The two escarpments were cut by hydro-erosion, which is represented in the dry wadis that are concentrated on the southwestern escarpment such as Wadi Al-Hita and Wadi Ar-Resw. The area of depression is about $1090 \mathrm{~km}^{2}$. Around a third of this area lies below sea level (the depression floor) (Figure 1)

The Depression has an elongated oval shape along axis of Northwest-Southeast for about $80 \mathrm{~km}$, the width of the the Depression varies from one sector to another, as it is narrow in its southeastern tip and widens towards the northwest with an average width of $18 \mathrm{~km}$.

The Depression elevations range from $29 \mathrm{~m}$ below sea level at the depression floor to $184 \mathrm{~m}$ above sea level at the southwestern escarpment (Figure 2).

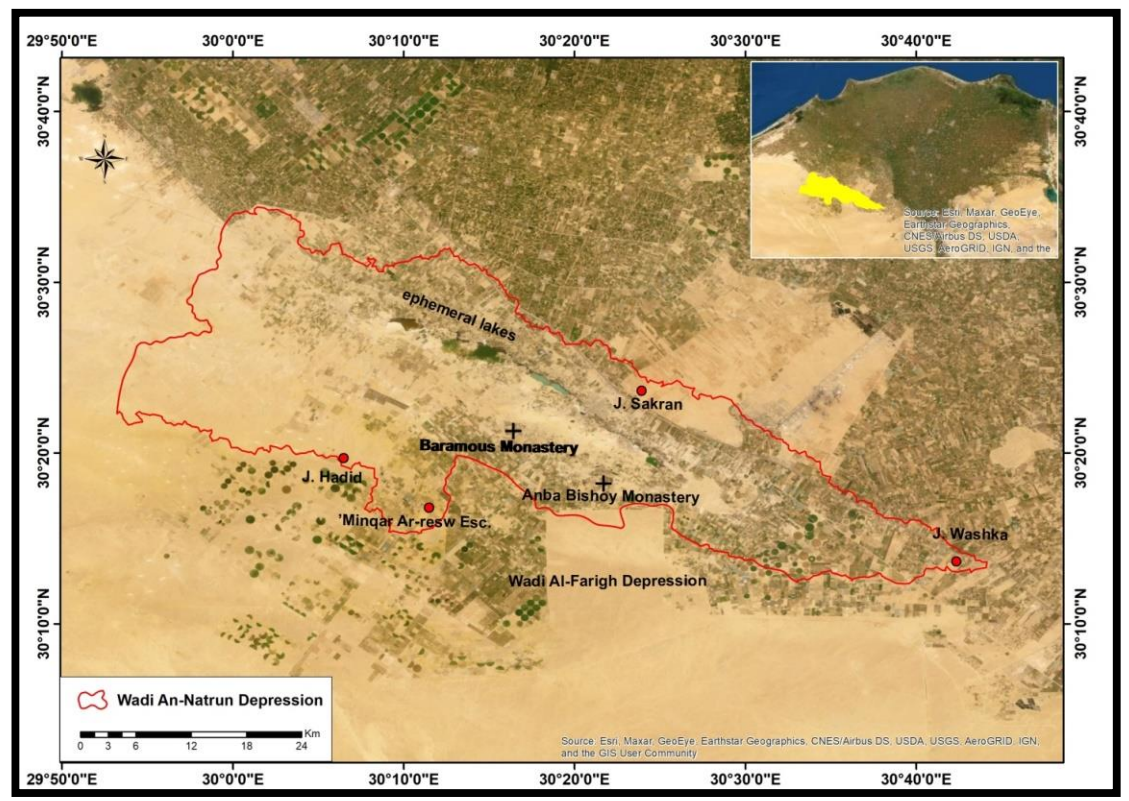

Source: Esri, Maxar, GeoEye, Earthstar Geographics, CNES/Airbus DS. USDA, USGS, AeroGRID, IGN, and the GIS User Community \& ASTER GDEM Version 2

Fig.1 Location of Wadi An-Natrun Depression 


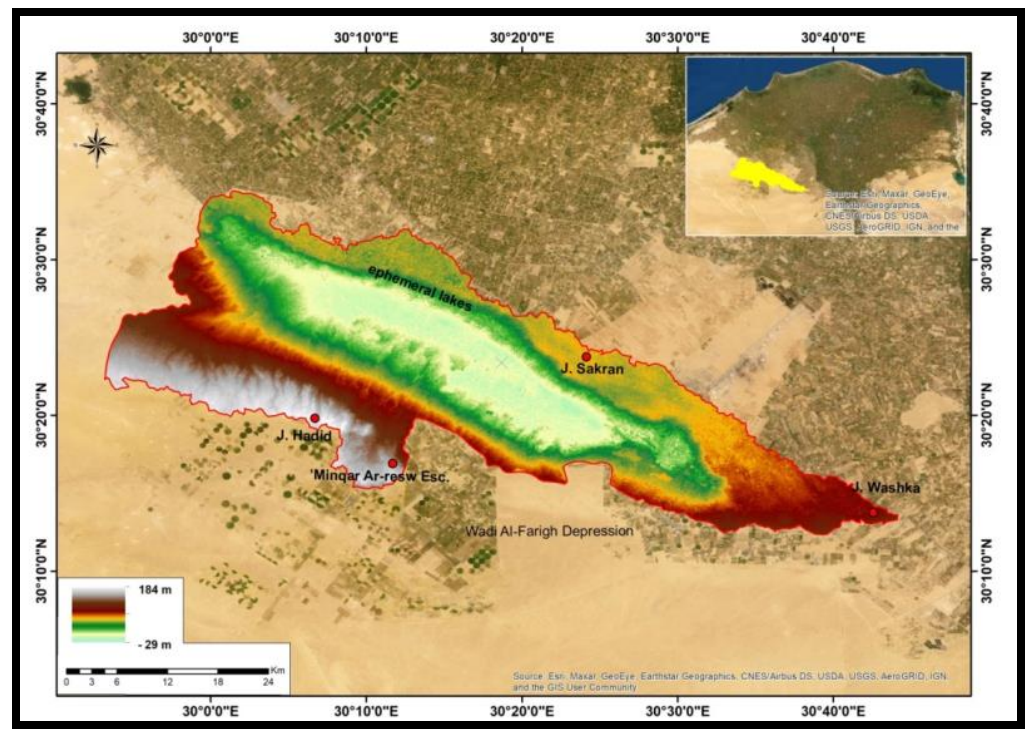

Source: ASTER GDEM Version 2

Fig. 2 Digital Elevation Model of Wadi An-Natrun Depression

The Depression Floor is occupying by shallow salt lakes are characteristic geomorphologic landforms namely Al-Fasdah, UmmRishah, Rusita, Al-Hamrah, Al-Zaajij, Al-Bidah, Al-Khadrah and Al-Jaar (Figure 3). Some of them are seasonal and ephemeral during the dry season, leaving behind Sabkhas (Figure 4), and others are permanent lakes, but their water bodies differ from one season to another due to the different water supplies. The sabkhas appears accompanying both types of lakes and the area of these sabkha varies, as will as the area of the water bodies of lakes.

Groundwater represents the main source of these lakes. Basically, the lakes water sources are as follows:

\section{- Groundwater}

The Depression includes four aquifers: the Miocene aquifer, the Pliocene aquifer, the Pleistocene aquifer, and the Holocene sand deposits aquifer.

\section{- The Miocene aquifer :}

It consists of sand, limestone and clay, and lies in the southern part of the depression connected to the 
Determining the Effectiveness of Using Remote... Dr. Islam Saber Amin

Pleistocene aquifer through a group of subsurface faults (Moselhy, 2005).

- The Pliocene aquifer :

It consists of marine and river sediments separated by a thick layer of shale, and the two layers contain groundwater, which may come out to the surface from the upper layer spontaneously in the eastern part of the lakes (El-Fayoumy, 1964 ).

- The Pleistocene aquifer :

This aquifer consists of layers of sand and gravel with high permeability (Encyclopedia of Western Desert, 1989 "in Arabic").

- The Holocene sand deposits aquifer:

This aquifer consists of highly permeable sand, Its water depth ranges between $1 \mathrm{~m}$ and $3 \mathrm{~m}$ from the surface. The water of this aquifer is moderately saline (Western Desert Encyclopedia, 1989 "in Arabic") .

\section{- The wastewater from irrigation and sewage}

The wastewater from irrigation and sewage is one of the important sources of lakes water in the Wadi An-Natrun Depression. The recent period has been characterized by large agricultural and urban development in the Depression, with the nature of the depression's topography, which is characterized by a closed central drainage system, the sewage water from irrigation and sewage seeps towards the floor of the depression and supplies the water of lakes

The sabkhas appears accompanying both types of lakes and the area of these sabkha varies, as will as the area of the water bodies of lakes. 


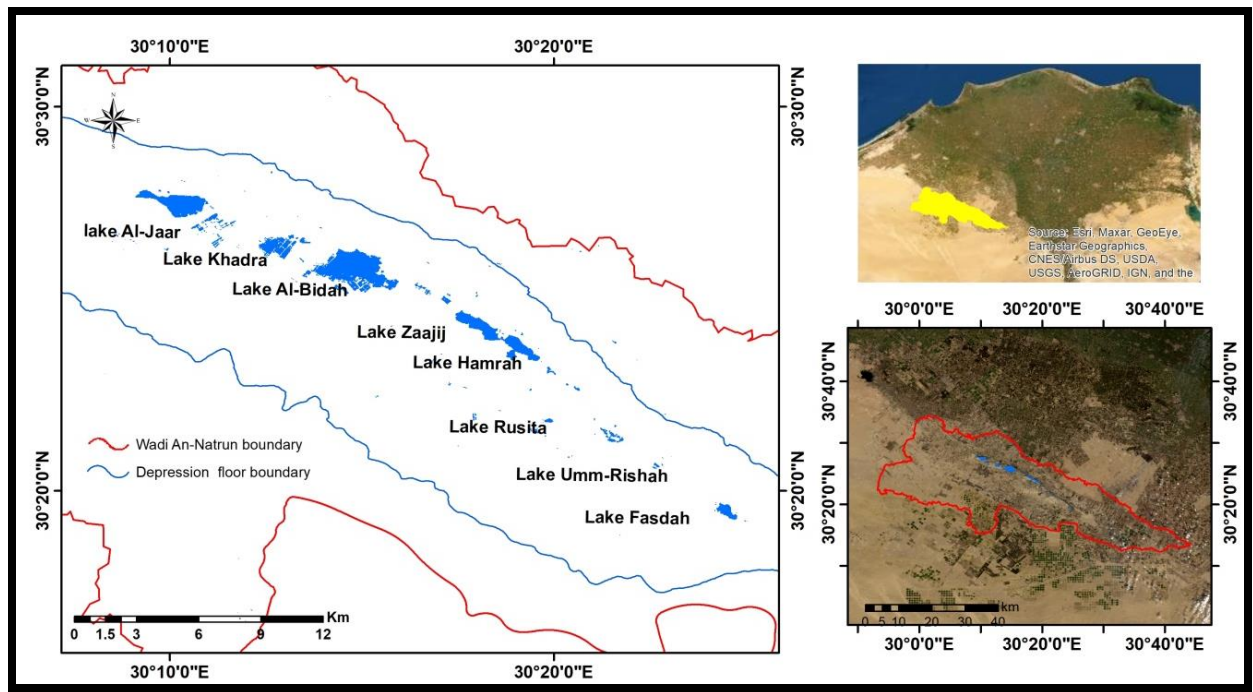

Source: landsat 8 (OLI) March 25, 2021

Fig. 3 Inland Saline Lakes of Wadi An-Natrun Depression.

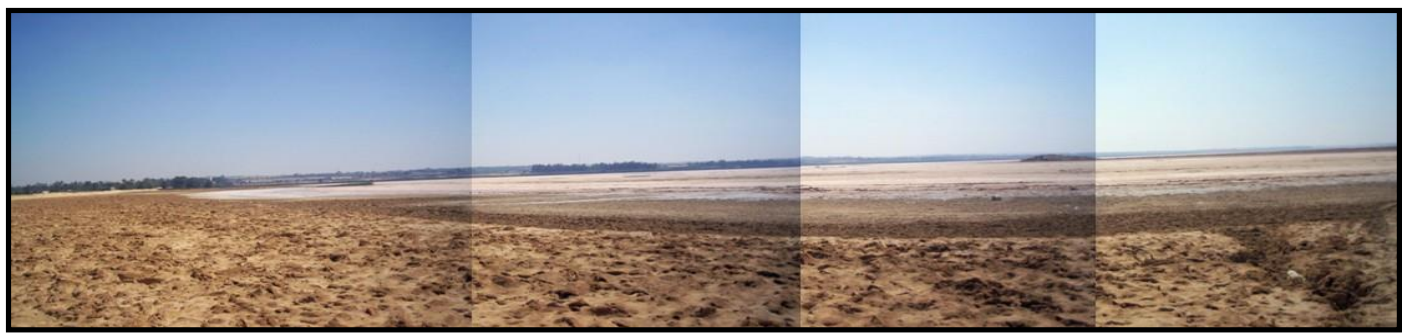

Fig. 4 Lake Umm-Rishah, July 2021.

Notice that most of the water body of the lake has dried up and turned into Sabkha.

Wadi Al-Natrun is covered by geological formations that range from lower Miocene and lower Pliocene, in addition to Pleistocene and Holocene sediments. In general, these formations consist of loose sand interspersed with layers of hard sand limestone, old alluvial deposits of sand and gravel, and Quaternary lake deposits (Figure 5). 
Determining the Effectiveness of Using Remote... Dr. Islam Saber Amin

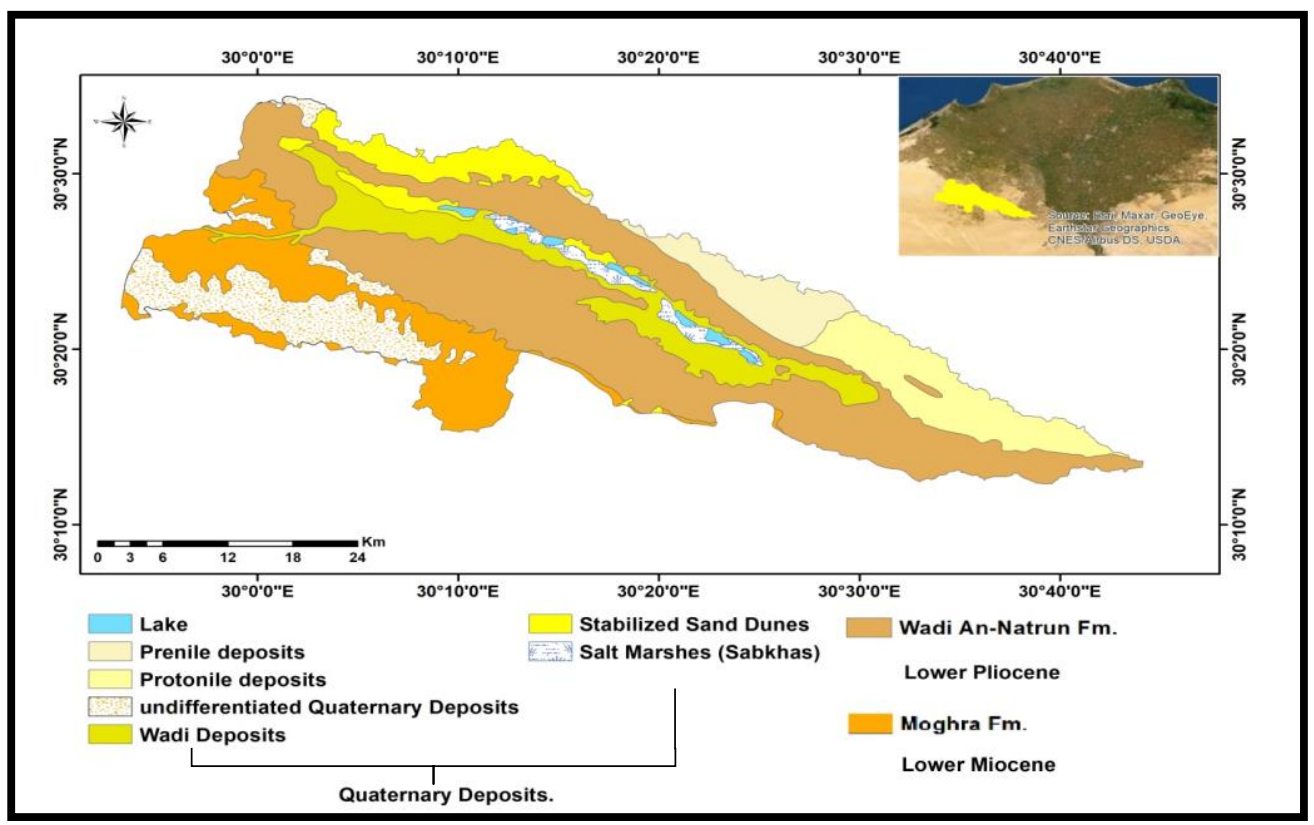

Source: Conoco Coral , Geological Map of Egypt 1:500000 , 1987 .

\section{Fig. 5 Geological Formations of Wadi An-Natrun Depression.}

The climate of Wadi Al-Natrun Depression is very arid. Based on data from the Egyptian metrological authority records (AnNatrun ground station 1990-2019), the mean annual temperature varies from $12.7{ }^{\circ} \mathrm{C}$ in January to $29.8^{\circ} \mathrm{C}$ in August, with very long summer "dry season" starts from the end of April and continues until the month of October. The rainfall is low and very variable, with occasional flash flood, the most recent of which were the 4th - 5 th November 2015 flash flood, The mean annual rainfall is $1.7 \mathrm{~mm}$ (1960-2019), it is concentrated in winter and spring, $0.1 \mathrm{~mm}$ in the spring months, $3.6 \mathrm{~mm}$ in the winter months and totally dry in the summer months . Wind velocities range between 11 and $20 \mathrm{~km} / \mathrm{h}$ in winter and summer respectively, winds being usually from the north, northeast and northwest ( Zahran \& Willis, 2009 ). 


\section{2- Material and Methods}

\subsection{Data used}

The current study is based on use of Landsat 8 Instruments. Operational Land Imager ( OLI ) Multispectral images covering areas of Wadi An-Natrun Depression sabkhas, in the Western Desert of Egypt. Five bands (Blue Band, Green Band, Red Band, Near-Infrared Band and SWIR 1 Band) out of eleven bands ( Coastal I Aerosol, Blue, Green, Red, NIR, Short Wavelength Infrared 1, Short Wavelength Infrared 2, Panchromatic, Cirrus, Long Wavelength Infrared1, and Long Wavelength Infrared2 ) were used for all classification and interpretation techniques.

\subsection{Pre-processing of data}

Working on Landsat 8 oLI images requires radiometric calibration . Gain bias correction, scattering effect and correction of the sun angle to convert digital numbers values ( DN ) into top of the atmosphere (TOA) spectral radiance, using the reflectance rescaling coefficients provided with the product. The DN values were converted into TOA reflectance using the following formula :

$\rho \lambda^{\prime}=M_{\rho} Q_{c a l}+A_{\rho}$ ( GUPTA, Kaushik, et al. , 2018 )

Where

$\rho \lambda^{\prime}=$ TOA planetary reflectance, without correction for solar angle. Note that $\rho \lambda$ ' does not contain a correction for the sun angle .

$\mathrm{M}_{\mathrm{p}}=$ Band-specific multiplicative rescaling factor from the metadata (REFLECTANCE_MULT_-BAND_x , where $\mathrm{x}$ is the band number)

$\mathrm{Q}_{\mathrm{cal}}=$ Quantized and calibrated standard product pixel values (DN)

$\mathrm{A}_{\mathrm{p}}=$ Band-specific additive rescaling factor from the metadata (REFLECTANCE_ADD_BAND_x , where $\mathrm{x}$ is the band number) 
Determining the Effectiveness of Using Remote... Dr. Islam Saber Amin

The sun angle have been corrected using the following formula:

$$
\rho \lambda=\frac{\rho \lambda^{\prime}}{\cos \left(\theta_{S Z}\right)}=\frac{\rho \lambda^{\prime}}{\sin \left(\theta_{S E}\right)}
$$

Where

$\rho \lambda=$ TOA planetary reflectance $\theta_{\mathrm{SE}}=$ Local sun elevation angle. The scene center sun elevation angle in degrees is provided in the metadata (SUN_ELEVATION). $\theta_{\mathrm{SE}}=$ Local solar zenith angle; $\theta_{\mathrm{SZ}}=90-\theta_{\mathrm{SE}}$.

\subsection{Salt-affected soil sampling and characterization}

Soil sampling was performed from July to August 2021 during the dry season through the field study of the study area (Figure 6), this period of time was characterized by a decrease of vegetation cover and a remarkable increase in salt concentration in the topsection of the soil .

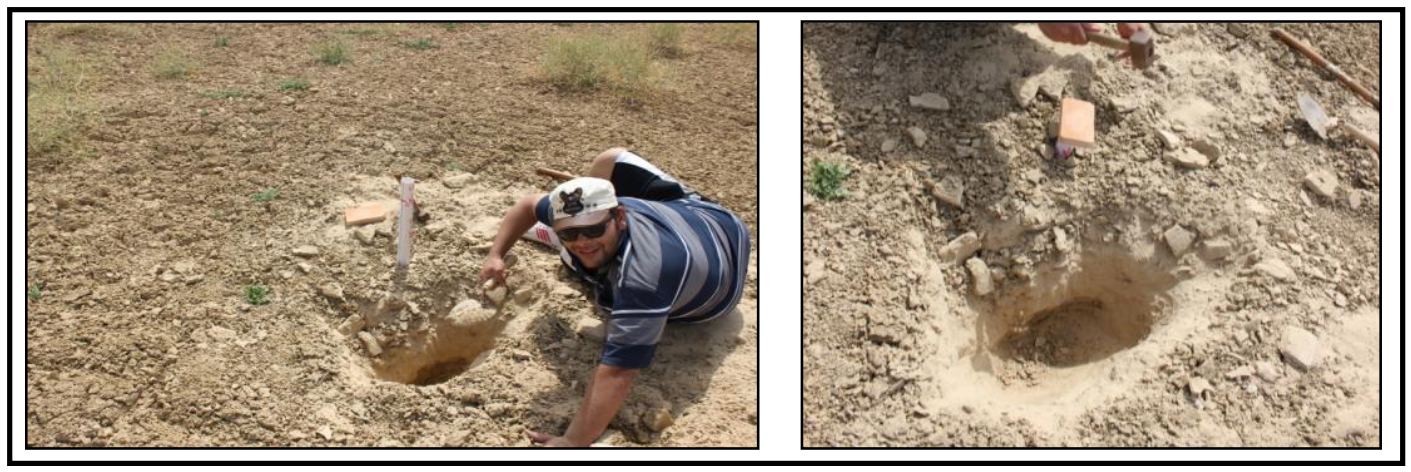

Fig. 6 Collecting Samples from the Soil Surface and Sub-surface during the Field Study . 
Random sampling was done, 22 sites were identified, and samples were collected from soil surface $(0-30 \mathrm{~cm}$.) and sub-surface ( $>30 \mathrm{~cm}$.) were collected. Total Station was used during the field work to obtain geographic locations of the soil sampling sites. Soil samples were analyzed in the laboratory of the Faculty of Environmental Agricultural Sciences, Al-Arish University, Egypt, to characterize the $\mathrm{pH}$ and electrical conductivity of saturation extract (EC).

\subsection{Spectral Indices}

\subsubsection{Salinity Index}

$S I 1=\sqrt{\text { Green } * \text { Red }}$ (AitLamqadem, et al. ,2018)

2.4.2. Salinity Index

$$
S I r=\sqrt{\text { Green }^{r}+\text { Red }^{r}+N I R^{r}}
$$

\subsubsection{Salinity Index}

$$
\text { (AitLamqadem, et al. ,2018) }
$$

$$
\begin{aligned}
& S I r=\sqrt{\text { Green }^{r}+N I R^{r}} \quad \text { (AitLamqadem, et } \\
& \text { al. ,2018) }
\end{aligned}
$$

\subsubsection{Salinity Index}

\subsubsection{Salinity Index}

$$
\text { SI } \varepsilon=\frac{\text { Green } * \text { Red }}{\text { Blue }} \text { (Mousavi, et al., 2017) }
$$

\subsubsection{Salinity Index}

$$
\text { SI० }=\frac{\text { Blue*Red }}{\text { Green }}(\text { Elhag, } 2016)
$$

$$
S I\rceil=\frac{\text { Blue-Red }}{\text { Blue+Red }} \quad \text { (Dehni \&Lounis , 2012) }
$$

\subsubsection{Vegetation Soil Salinity Index}

$$
\text { VSSI }=r * \text { Green }-\circ *(\text { Red }+N I R)
$$

(Dehni \& Lounis, 2012 )

2.4.8. Normalized Difference Salinity Index-NDSI

$$
N D S I=\frac{\operatorname{Red}-N I R}{\operatorname{Red}+N I R}(\text { Khan, et al. ,2001 ) }
$$


Determining the Effectiveness of Using Remote... Dr. Islam Saber Amin

\subsection{The salinity estimation and validation}

Linear and multiple regression models were applied to determine the relationship between the salinety values obtained from the laboratory analyzes and the salinety values derived from the remote sensing data. Whereas, the regression models have a well-defined coefficient (R2).

\section{Results and Discussion}

\subsection{Physico-chemical characteristics of Sabkhs soils}

The Wadi An-Natrun Sabkhas soils was characterized as salinealkali soils, the sabkhas soils $\mathrm{pH}$ were ranged between slightly alkaline (7.4) in Sabkha of lake Al-Jaar and very strongly alkaline (9.2) in Sabkha of lake Hamrah (Table 1). These soil samples were grouped into classes of (Table 2):

- slightly alkaline ( $7.4:<7.9)$ : This category includes only two samples, representing $9.1 \%$ of the total samples, with a mean of 7.6, located in the sabkha of Lake Al-Jaar.

- moderately alkaline $(7.9:<8.6)$ : This category includes six samples, representing $27.3 \%$ of the total samples, with a mean of 8.1, where one sample is located in the sabkha of Lake Al-Jaar, three samples are located in the sabkha of Lake Al- Khadra, and two samples are located in the sabkhat of Lake Al- Bidah.

- strongly alkaline ( 8.6 : 9.0 ) : This category includes eleven samples, representing $50.0 \%$ of the total samples, with a mean of 8.8, where three samples are located in the sabkha of Lake Al- Fasidah, three samples are located in the sabkha of Lake Al- Zaajij, three samples are located in the sabkha of Lake Umm-Rishah, and two samples are located in the sabkha of Lake Rusita .

- and Very strongly alkaline ( $>$ 9.0 ) : This category includes only three samples, representing $13.6 \%$ of the total samples, with a mean of 9.2 , where tow samples are located 
in the sabkha of Lake Al-Hamrah, and last sample is located in the sabkh of Lake Rusita .

It is clear from the above that the sabkha of Lake Hamrah is the highest alkaline in the study area, and that all the samples collected from the sabkhas of Lakes Al- Zaajij, Al- Fasidah, Umm-Rishah and Rusita are Strongly alkaline category, which means $63.6 \%$ of the total samples in the study are range in ialkalinity values between Strongly alkaline and Very strongly alkaline.

Table 1. The PH of Sabkhas Soils Samples

\begin{tabular}{ccc|ccc}
\hline $\begin{array}{c}\text { sample } \\
\text { No. }\end{array}$ & sample location & PH & $\begin{array}{c}\text { sample } \\
\text { No. }\end{array}$ & sample location & PH \\
\hline 1 & Sabkha of lake Al-Jaar & 7.4 & 12 & Sabkha of lake Al-Hamrah & 9.2 \\
2 & Sabkha of lake Al-Jaar & 7.7 & 13 & Sabkha of lake Al-Hamrah & 9.1 \\
3 & Sabkha of lake Al-Jaar & 7.9 & 14 & Sabkha of lake Rusita & 9.2 \\
4 & Sabkha of lake Al-Khadrah & 8.3 & 15 & Sabkha of lake Rusita & 9 \\
5 & Sabkha of lake Al-Khadrah & 8 & 16 & Sabkha of lake Rusita & 9 \\
6 & Sabkha of lake Al-Khadrah & 8.1 & 17 & Sabkha of lake Um-Rishah & 8.8 \\
7 & Sabkha of lake Al-Bidah & 8.1 & 18 & Sabkha of lake Um-Rishah & 8.7 \\
8 & Sabkha of lake Al-Bidah & 8.2 & 19 & Sabkha of lake Um-Rishah & 9 \\
9 & Sabkha of lake Al-Zaajij & 8.7 & 20 & Sabkha of lake Fasidah & 8.8 \\
10 & Sabkha of lake Al-Zaajij & 8.9 & 21 & Sabkha of lake Fasidah & 8.6 \\
11 & Sabkha of lake Al-Zaajij & 9 & 22 & Sabkha of lake Fasidah & 8.7 \\
\hline
\end{tabular}

The analysis was carried out in the laboratory of the Faculty of Environmental Agricultural Sciences , Al-Arish University, Egypt

Table 2. The PH Characterization of Wadi An-Natrun Sabkhas Soils

\begin{tabular}{lcccc}
\hline Statistics & Slightly alkaline & Moderately alkaline & $\begin{array}{c}\text { Strongly } \\
\text { alkaline }\end{array}$ & $\begin{array}{c}\text { Very strongly } \\
\text { alkaline }\end{array}$ \\
\hline Sum & 2.0 & 6.0 & 11.0 & 3.0 \\
Mean & 7.6 & 8.1 & 8.8 & 9.2 \\
Maximum & 7.7 & 8.3 & 9.0 & 9.2 \\
Minimum & 7.4 & 7.9 & 8.6 & 9.1 \\
Standard & & & & 0.1 \\
deviation & 0.2 & 0.1 & & 0.1 \\
\hline
\end{tabular}


The electrical conductivity of saturation extract of soil of Sabkhas soils samples (ECe) had very high, it was varied from (21.7 $\mathrm{ds} / \mathrm{m})$ in Sabkha of lake Al-Bidah and $(110.1 \mathrm{ds} / \mathrm{m})$ in Sabkha of lake Rusita (Table 3). These samples were grouped into classes of (Table 4) :

- Moderate salinity ( $21.7 \mathrm{ds} / \mathrm{m}-34.9 \mathrm{ds} / \mathrm{m}$ ): This category includes eleven samples, representing $50.0 \%$ of the total samples, with a mean of $30.5 \mathrm{ds} / \mathrm{m}$, where three samples are located in the sabkha of Lake Umm -Rishah, tow samples are located in the sabkh of Lake Al- Bidah, tow samples are located in the sabkha of Lake Al-Jaar, two samples are located in the sabkha of Lake Al-Zaajij, and two samples are located in the sabkha of Lake Al- Fasidah

- Strong salinity ( $35.0 \mathrm{ds} / \mathbf{m}-\mathbf{5 9 . 8} \mathrm{ds} / \mathbf{m})$ : This category includes eight samples, representing $36.4 \%$ of the total samples, with a mean of $44.3 \mathrm{ds} / \mathrm{m}$, where three samples are located in the sabkha of Lake Al- Khadrah , tow samples are located in the sabkh of Lake Al- Hamrah, one sample is located in the sabkha of Lake Al-Jaar, one sample is located in the sabkha of Lake Al-Zaajij, and one sample are located in the sabkha of Lake Al- Fasidah.

- Very strong salinity ( $>\mathbf{5 9 . 8} \mathbf{d s} / \mathbf{m}$ ): This category includes three samples, representing $13.6 \%$ of the total samples, with a mean of $109.0 \mathrm{ds} / \mathrm{m}$, where all samples are located in the sabkha of Lake Rusita.

It is clear from the above that $50 \%$ of the total samples collected from the sabkhas of the study area reached the electrical conductivity values of the electrode conductivity $\geq 35.5 \mathrm{ds} / \mathrm{m}$, and their salinity values range between Strong salinity and very Strong salinity. 
Table 3. The ECe of Sabkhas soils samples

\begin{tabular}{|c|c|c|c|c|c|}
\hline $\begin{array}{c}\text { sample } \\
\text { No. }\end{array}$ & sample location & $\begin{array}{l}\mathrm{ECe} \\
(\mathrm{ds} / \mathrm{m})\end{array}$ & $\begin{array}{c}\text { sample } \\
\text { No. }\end{array}$ & sample location & $\begin{array}{l}\mathrm{ECe} \\
(\mathrm{ds} / \mathrm{m})\end{array}$ \\
\hline 1 & Sabkha of lake Al-Jaar & 32.1 & 12 & Sabkha of lake Al-Hamrah & 37.7 \\
\hline 2 & Sabkha of lake Al-Jaar & 35 & 13 & Sabkha of lake Al-Hamrah & 35.2 \\
\hline 3 & Sabkha of lake Al-Jaar & 33.6 & 14 & Sabkha of lake Rusita & 109.3 \\
\hline 4 & $\begin{array}{c}\text { Sabkha of lake Al- } \\
\text { Khadrah }\end{array}$ & 55.4 & 15 & Sabkha of lake Rusita & 107.7 \\
\hline 5 & $\begin{array}{c}\text { Sabkha of lake Al- } \\
\text { Khadrah }\end{array}$ & 59.1 & 16 & Sabkha of lake Rusita & 110.1 \\
\hline 6 & $\begin{array}{c}\text { Sabkha of lake Al- } \\
\text { Khadrah }\end{array}$ & 59.8 & 17 & Sabkha of lake Um-Rishah & 26.5 \\
\hline 7 & Sabkha of lake Al-Bidah & 33.2 & 18 & Sabkha of lake Um-Rishah & 26.9 \\
\hline 8 & Sabkha of lake Al-Bidah & 21.7 & 19 & Sabkha of lake Um-Rishah & 27.2 \\
\hline 9 & Sabkha of lake Al-Zaajij & 32.5 & 20 & Sabkha of lake Fasidah & 35.6 \\
\hline 10 & Sabkha of lake Al-Zaajij & 36.3 & 21 & Sabkha of lake Fasidah & 32.9 \\
\hline 11 & Sabkha of lake Al-Zaajij & 34.9 & 22 & Sabkha of lake Fasidah & 34.4 \\
\hline
\end{tabular}

The analysis was carried out in the laboratory of the Faculty of Environmental Agricultural Sciences, Al-Arish University, Egypt

Table 4. The ECe characterization of Wadi An-Natrun Sabkhas soils

\begin{tabular}{cccc}
\hline Statistics & Moderate salinity & Strong salinity & Very Strong salinity \\
\hline Sum & 11.0 & 8.0 & 3.0 \\
Mean & 30.5 & 44.3 & 109.0 \\
Maximum & 21.7 & 35.0 & 107.7 \\
Minimum & 34.9 & 59.8 & 110.1 \\
Standard deviation & 4.3 & 11.6 & 1.2
\end{tabular}

The electrical conductivity of saturation extract of soil is related to the concentration of salts in the soil solution, so the concentration of the salts in the saturation extract of soil of Sabkhas soils samples were ranged between ( 13888 parts per million - ppm - ) in Sabkha of lake Al-Bidah and ( 70464 ppm ) in Sabkha of lake Rusita . The percentage of salts in the soil solution also ranged between $1.3 \%$ in Sabkha of lake Al-Bidah and 7\% in Sabkha of lake Rusita (Table 5) . 
Determining the Effectiveness of Using Remote... Dr. Islam Saber Amin

\section{Table 5. The Concentration of Salts in the Soil Solution of Sabkhas Soils Samples}

\begin{tabular}{|c|c|c|c|c|c|c|c|}
\hline $\begin{array}{l}\text { sample } \\
\text { No. }\end{array}$ & sample location & $\%$ & Ppm & $\begin{array}{l}\text { sample } \\
\text { No. }\end{array}$ & sample location & $\%$ & Ppm \\
\hline 1 & Sabkha of lake Al-Jaar & 2.1 & 20544 & 12 & $\begin{array}{c}\text { Sabkha of lake } \\
\text { Al-Hamrah }\end{array}$ & 2.4 & 22400 \\
\hline 2 & Sabkha of lake Al-Jaar & 2.2 & 22400 & 13 & $\begin{array}{l}\text { Sabkha of lake } \\
\text { Al-Hamrah }\end{array}$ & 2.3 & 21504 \\
\hline 3 & Sabkha of lake Al-Jaar & 2.2 & 21504 & 14 & $\begin{array}{l}\text { Sabkha of lake } \\
\text { Rusita }\end{array}$ & 7 & 35456 \\
\hline 4 & $\begin{array}{c}\text { Sabkha of lake Al- } \\
\text { Khadrah }\end{array}$ & 3.5 & 35456 & 15 & $\begin{array}{l}\text { Sabkha of lake } \\
\text { Rusita }\end{array}$ & 6.9 & 37824 \\
\hline 5 & $\begin{array}{c}\text { Sabkha of lake Al- } \\
\text { Khadrah }\end{array}$ & 3.8 & 37824 & 16 & $\begin{array}{l}\text { Sabkha of lake } \\
\text { Rusita }\end{array}$ & 7 & 38272 \\
\hline 6 & $\begin{array}{c}\text { Sabkha of lake Al- } \\
\text { Khadrah }\end{array}$ & 3.8 & 38272 & 17 & $\begin{array}{l}\text { Sabkha of lake } \\
\text { Um-Rishah }\end{array}$ & 1.7 & 21248 \\
\hline 7 & Sabkha of lake Al-Bidah & 2.1 & 21248 & 18 & $\begin{array}{c}\text { Sabkha of lake } \\
\text { Um-Rishah }\end{array}$ & 1.7 & 13888 \\
\hline 8 & Sabkha of lake Al-Bidah & 1.4 & 13888 & 19 & $\begin{array}{l}\text { Sabkha of lake } \\
\text { Um-Rishah }\end{array}$ & 1.7 & 20800 \\
\hline 9 & Sabkha of lake Al-Zaajij & 2.1 & 20800 & 20 & $\begin{array}{l}\text { Sabkha of lake } \\
\text { Fasidah }\end{array}$ & 2.3 & 23232 \\
\hline 10 & Sabkha of lake Al-Zaajij & 2.3 & 23232 & 21 & $\begin{array}{l}\text { Sabkha of lake } \\
\text { Fasidah }\end{array}$ & 2.1 & 20544 \\
\hline 11 & Sabkha of lake Al-Zaajij & 2.2 & 20544 & 22 & $\begin{array}{l}\text { Sabkha of lake } \\
\text { Fasidah }\end{array}$ & 2.2 & 22400 \\
\hline
\end{tabular}

The analysis was carried out in the laboratory of the Faculty of Environmental Agricultural Sciences , Al-Arish University, Egypt

\subsection{Soil Salinity with Salinity Indices}

Salinity Indices were applied on the floor of Wadi An-Natrun Depression to perform a comparison between all Salinity Indices to clarify the most accurate of these Indices for the auto-detection of sabkha. On the other hand, a statistical comparison was made between the results of the application of Indices and the salinity values extracted in the laboratory. (Figure 7) illustrates the application of salinity Indices using Landsat satellite images for the study area. 


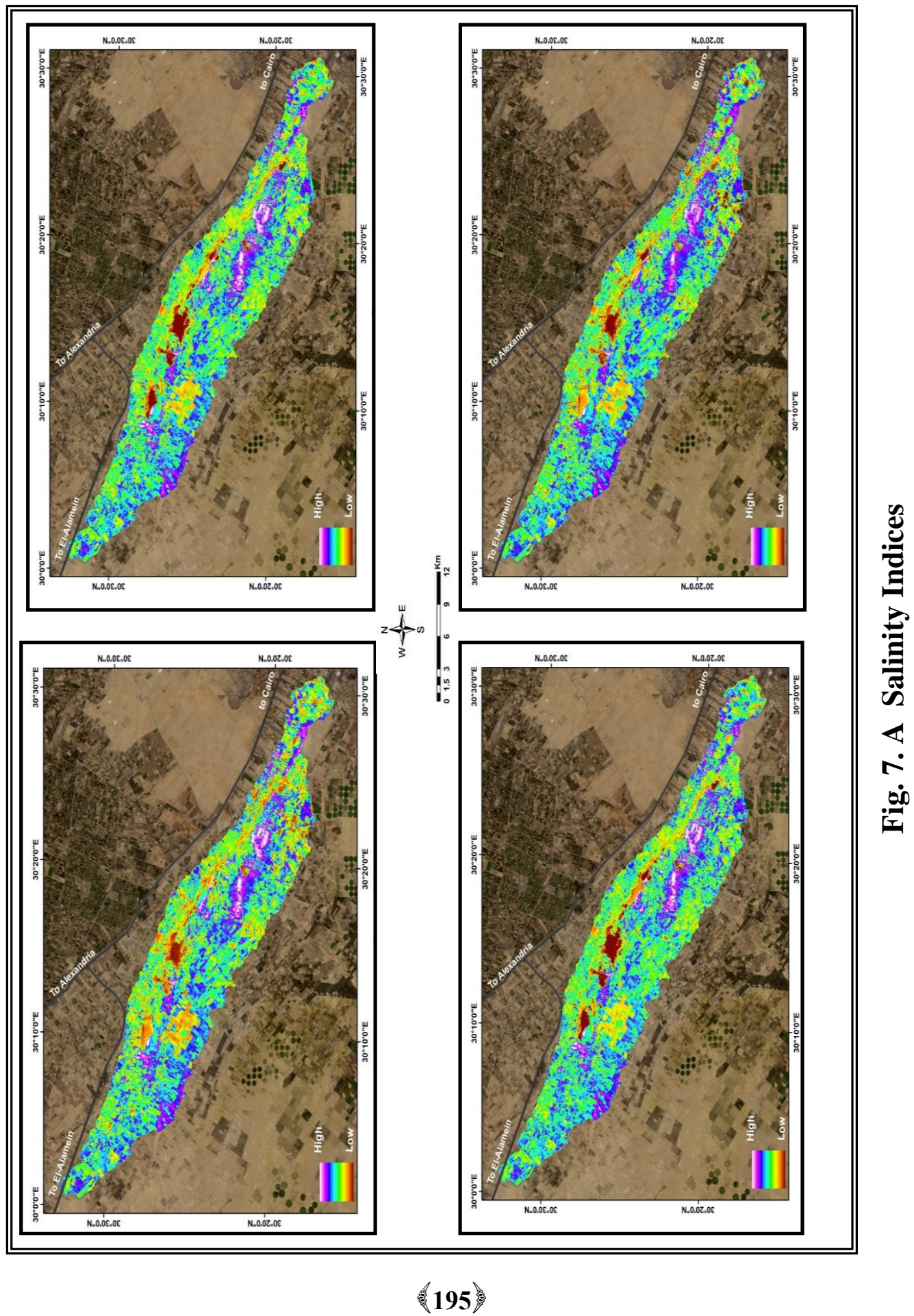


Determining the Effectiveness of Using Remote... Dr. Islam Saber Amin

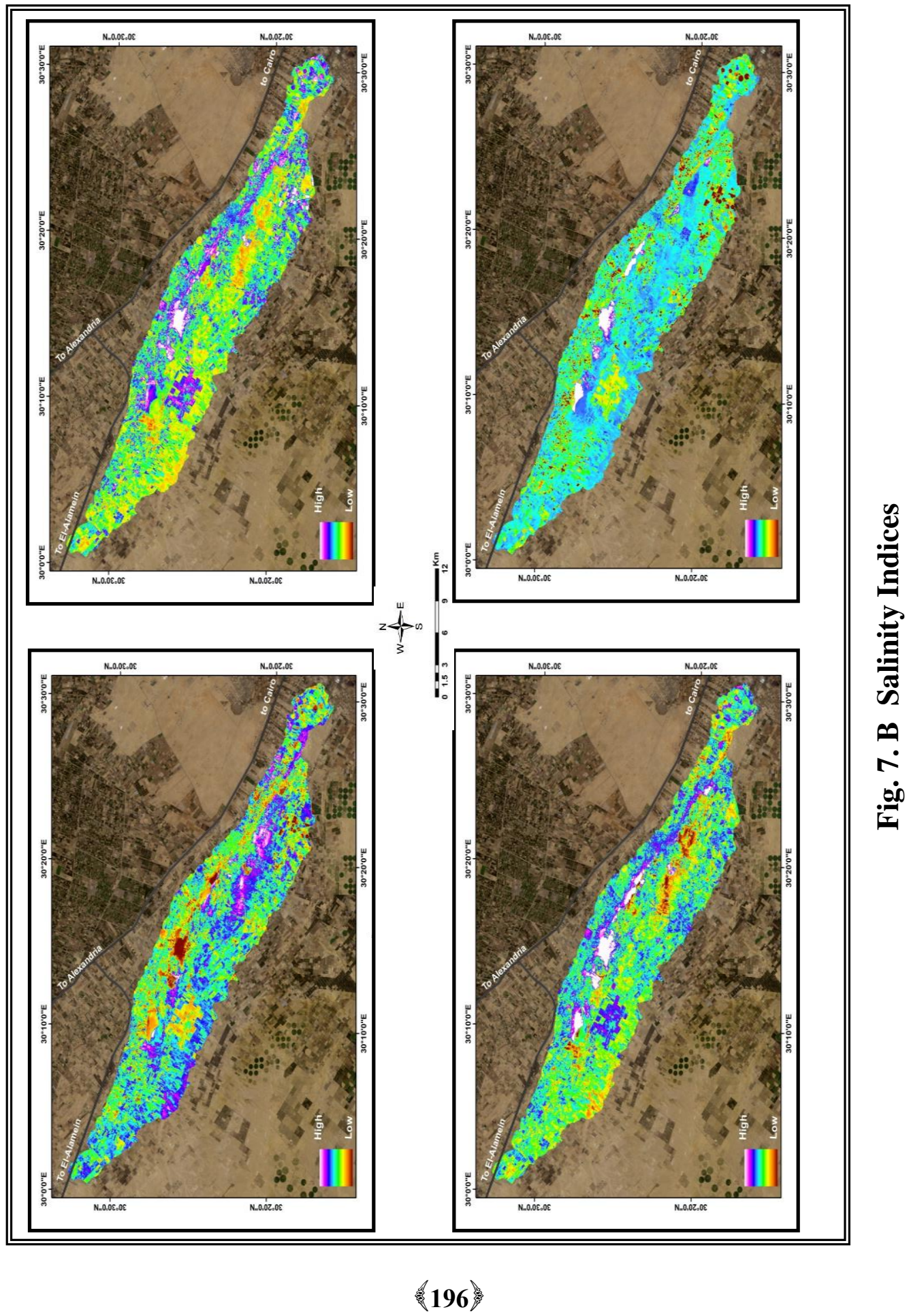




\subsection{Statistical validation}

Linear and multiple regression models were used to find the best fit between field sampling results and satellite image indices. The application of the multiple regression model indicates that the (standard) multiple regression model is the most suitable model with a correlation coefficient value of 0.984 and a determination coefficient of 0.968 (Table 6). Also, all the correlation values were negative, strong, medium, and statistically significant (Table 7). The model also showed that the NDSI index is the most influential indices in the regression line equation with statistical significance less than 0.05 (Table 8)

Table (9) and Figure (8) illustrate the results of simple linear regression models between ECe values on the one hand and on the other hand one of the salinity indices. NDSI index has shown highest correlation with ECe was 0.872 and determination coefficient $\left(\mathrm{R}^{2}\right)$ was 0.761 , followed by the NSSI index with a correlation value (R) of 0.796 and a determination coefficient $\left(\mathrm{R}^{2}\right)$ of 0.634 .

Table 6. Model Summary

\begin{tabular}{ll|l|l|l|l} 
Model & $\mathrm{R}$ & R Square & $\begin{array}{l}\text { Adjusted } \\
\text { Square }\end{array}$ & $\mathrm{R}$ & $\begin{array}{l}\text { Std. Error of the } \\
\text { Estimate }\end{array}$ \\
\hline 1 & $.984^{\mathrm{a}}$ & .968 & .949 & 6.19531 \\
\hline
\end{tabular}

a. Predictors: (Constant), NDSI, SI2, SI6, SI4, SI5, SI3, NSSI, SI1

b. Dependent Variable: ECe 
Determining the Effectiveness of Using Remote... Dr. Islam Saber Amin

Tabel 7. Correlations Matrix between Laboratory ECe Results Salinity Indices

\begin{tabular}{|c|c|c|c|c|c|c|c|c|c|c|}
\hline & & $\mathrm{ECe}$ & SI1 & SI2 & SI3 & SI4 & SI5 & SI6 & NSSI & NDSI \\
\hline \multirow{9}{*}{$\begin{array}{l}\text { Pearson } \\
\text { Correlation }\end{array}$} & $\mathrm{ECe}$ & 1.000 & .690 & .672 & .695 & .628 & .710 & .759 & .796 & .872 \\
\hline & SI1 & .690 & 1.000 & .608 & .823 & .977 & .756 & .675 & .828 & .669 \\
\hline & SI2 & .672 & .608 & 1.000 & .756 & .562 & .745 & .542 & .697 & .448 \\
\hline & SI3 & .695 & .823 & .756 & 1.000 & .782 & .859 & .509 & .749 & .538 \\
\hline & SI4 & .628 & .977 & .562 & .782 & 1.000 & .741 & .692 & .807 & .631 \\
\hline & SI5 & .710 & .756 & .745 & .859 & .741 & 1.000 & .743 & .897 & .538 \\
\hline & SI6 & .759 & .675 & .542 & .509 & .692 & .743 & 1.000 & .841 & .601 \\
\hline & NSSI & .796 & .828 & .697 & .749 & .807 & .897 & .841 & 1.000 & .667 \\
\hline & NDSI & .872 & .669 & .448 & .538 & .631 & .538 & .601 & .667 & 1.000 \\
\hline \multirow[t]{9}{*}{ Sig. (1-tailed) } & $\mathrm{ECe}$ & $\cdot$ & .000 & .000 & .000 & .001 & .000 & .000 & .000 & .000 \\
\hline & SI1 & .000 & & .001 & .000 & .000 & .000 & .000 & .000 & .000 \\
\hline & SI2 & .000 & .001 & . & .000 & .003 & .000 & .005 & .000 & .018 \\
\hline & SI3 & .000 & .000 & .000 & . & .000 & .000 & .008 & .000 & .005 \\
\hline & SI4 & .001 & .000 & .003 & .000 & . & .000 & .000 & .000 & .001 \\
\hline & SI5 & .000 & .000 & .000 & .000 & .000 & . & .000 & .000 & .005 \\
\hline & SI6 & .000 & .000 & .005 & .008 & .000 & .000 & & .000 & .002 \\
\hline & NSSI & .000 & .000 & .000 & .000 & .000 & .000 & .000 & & .000 \\
\hline & NDSI & .000 & .000 & .018 & .005 & .001 & .005 & .002 & .000 & . \\
\hline
\end{tabular}

\section{Tabel 8. Multiple Regression Model Coefficients}

\begin{tabular}{|c|c|c|c|c|c|c|}
\hline \multirow[b]{2}{*}{ Model } & & \multicolumn{2}{|c|}{ Unstandardized Coefficients } & \multirow{2}{*}{$\begin{array}{l}\text { Standardized } \\
\text { Coefficients } \\
\text { Beta }\end{array}$} & \multirow[b]{2}{*}{$\mathrm{t}$} & \multirow[b]{2}{*}{ Sig. } \\
\hline & & $\mathrm{B}$ & Std. Error & & & \\
\hline \multirow[t]{9}{*}{1} & (Constant) & $-15.524-$ & 8.232 & & $-1.886-$ & .082 \\
\hline & SI1 & .552 & .863 & .194 & 640 & .533 \\
\hline & SI2 & .247 & .247 & .084 & .999 & .336 \\
\hline & SI3 & 1.593 & .391 & .676 & 4.070 & .001 \\
\hline & SI4 & $-1.748-$ & .642 & $-.705-$ & $-2.722-$ & .017 \\
\hline & SI5 & $-.882-$ & .345 & $-.466-$ & $-2.559-$ & .024 \\
\hline & SI6 & 1.103 & .220 & .549 & 5.013 & .000 \\
\hline & NSSI & .310 & .239 & .225 & 1.294 & .218 \\
\hline & NDSI & .737 & .097 & .557 & 7.606 & .000 \\
\hline
\end{tabular}

a. Dependent Variable: ECe 
Tabel 9. Accuracy Assessment between Salinity Indices and Electrical Conductivity (ECe)

\begin{tabular}{lllllll}
\hline Index & $\mathrm{R}$ & $\mathrm{R}^{2}$ & Adjusted $\mathrm{R}^{2}$ & Std. error of estimate & F Value & Sig. \\
\hline SI1 & 0.690 & 0.476 & 0.449 & 20.285 & 18.134 & 0.000 \\
SI2 & 0.672 & 0.452 & 0.425 & 20.734 & 16.501 & 0.001 \\
SI3 & 0.695 & 0.483 & 0.457 & 20.142 & 18.679 & 0.000 \\
SI4 & 0.628 & 0.394 & 0.364 & 21.803 & 13.009 & 0.002 \\
SI5 & 0.710 & 0.504 & 0.479 & 19.730 & 20.312 & 0.000 \\
SI6 & 0.759 & 0.577 & 0.555 & 18.225 & 27.243 & 0.000 \\
NSSI & 0.796 & 0.634 & 0.616 & 16.947 & 34.639 & 0.000 \\
NDSI & 0.872 & 0.761 & 0.749 & 13.690 & 63.732 & 0.000 \\
\hline
\end{tabular}


Determining the Effectiveness of Using Remote... Dr. Islam Saber Amin
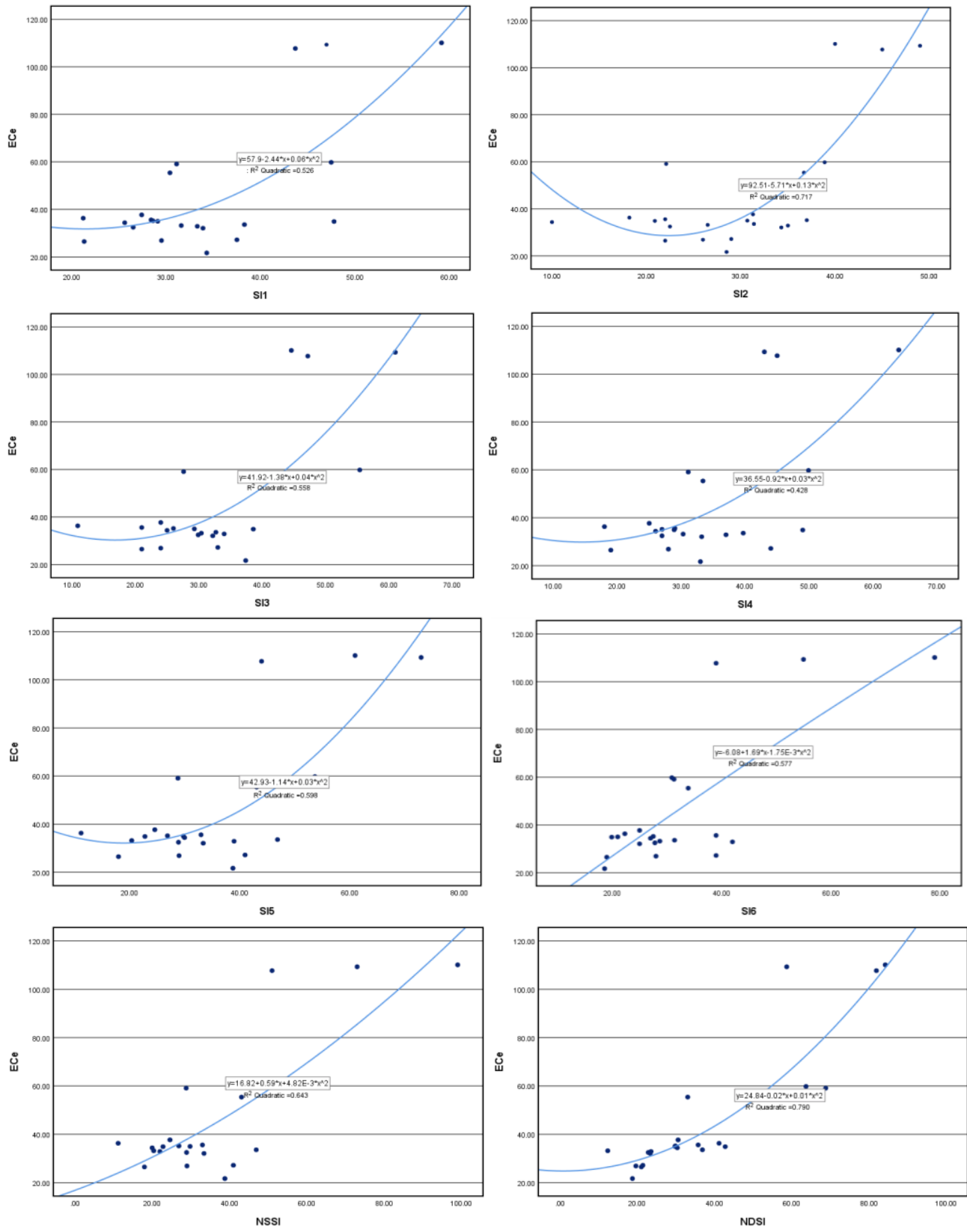

Fig. 8 Correlations between Electrical Conductivity (ECe) and Spectral Reflectance of Salinity Indices . 


\subsection{Enhanced soil salinity index}

The Enhanced soil salinity index (Figure 9) was deduced based on the use of near-infrared (NIR) spectral reflection, which emphasizes biomass content, shorelines and water masking, and short-wave infrared (SWIR) 2 that improved moisture content of soil and vegetation; penetrates thin clouds, and also used in mapping \& bright object mapping (Table 10), with subtracting the values of the Normalized Difference Vegetation Index ( NDVI) :

$$
\mathrm{ESSI}=\frac{N I R-S W I R Y}{N I R+S W I R Y}-N D V I
$$

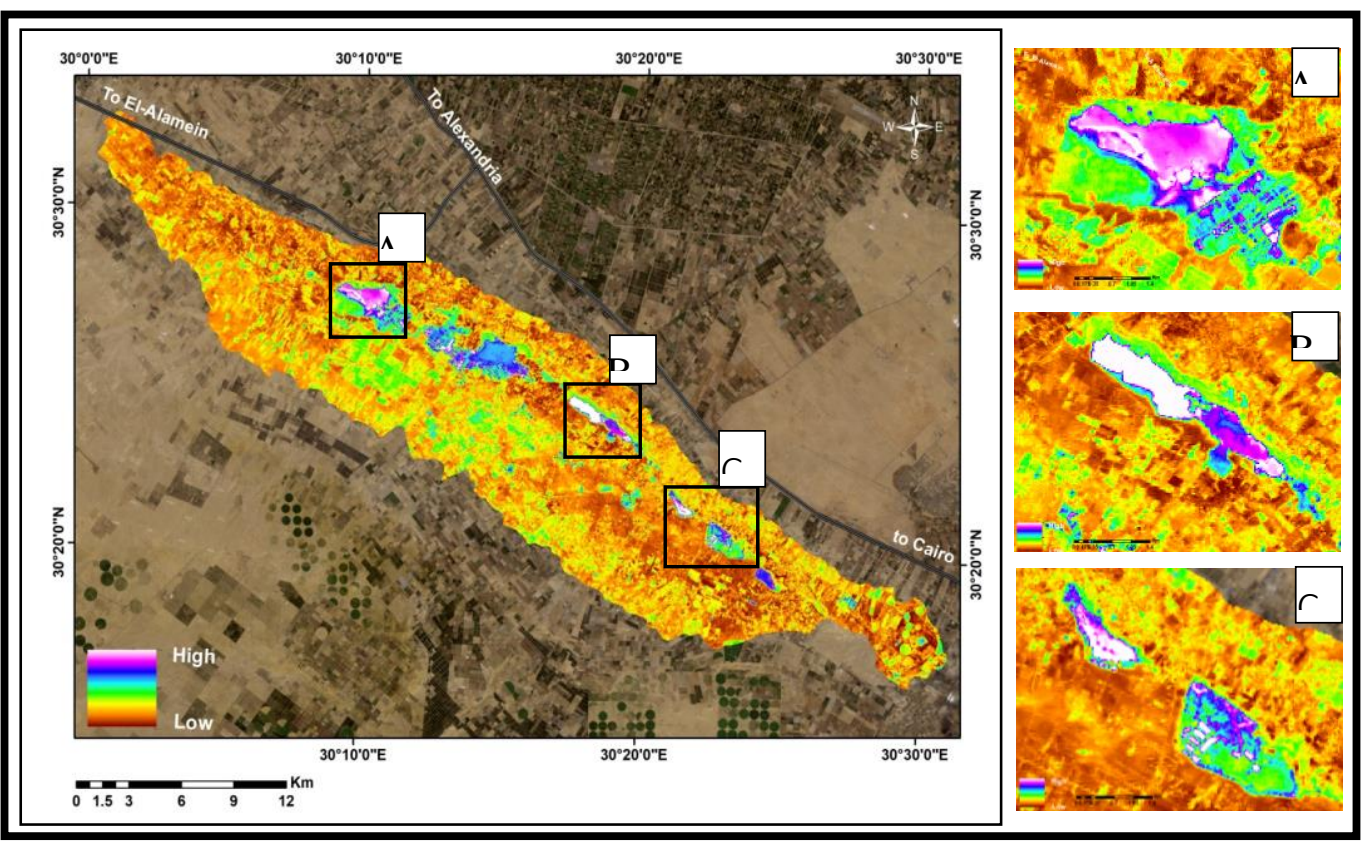

Source: landsat 8 (OLI) July 25, 2021

Fig. 9 Enhanced Soil Salinity Index 
Determining the Effectiveness of Using Remote... Dr. Islam Saber Amin

\section{Table 10. Spectral Bands Informations of Landsat-8 OLI}

\begin{tabular}{|c|c|c|c|}
\hline Band & $\begin{array}{l}\text { Resolution } \\
\quad(\mathbf{m})\end{array}$ & $\begin{array}{l}\text { Wavelength } \\
(\mu \mathrm{m})\end{array}$ & Type of Information and Purpose \\
\hline 1- coastal aerosol & 30.00 & $0.43-0.45$ & Coastal and aerosol studies \\
\hline 2 - blue & 30.00 & $0.45-0.51$ & $\begin{array}{l}\text { Bathymetric mapping, distinguishing } \\
\text { soil from vegetation and deciduous } \\
\text { from coniferous vegetation }\end{array}$ \\
\hline 3 - green & 30.00 & $0.53-0.59$ & $\begin{array}{l}\text { Emphasizes peak vegetation, which } \\
\text { is useful for assessing plant vigor }\end{array}$ \\
\hline $4-$ red & 30.00 & $0.64-0.67$ & Discriminates vegetation slopes \\
\hline $5-(\mathrm{NIR})$ & 30.00 & $0.85-0.88$ & $\begin{array}{l}\text { Emphasizes biomass content and } \\
\text { shorelines \& reflectance for water } \\
\text { masking }\end{array}$ \\
\hline $6-($ SWIR) 1 & 30.00 & $1.57-1.65$ & $\begin{array}{l}\text { Discriminates moisture content of } \\
\text { soil and vegetation; penetrates thin } \\
\text { clouds }\end{array}$ \\
\hline 7 - (SWIR) 2 & 30.00 & $2.11-2.29$ & $\begin{array}{l}\text { Improved moisture content of soil } \\
\text { and vegetation; penetrates thin } \\
\text { clouds \& bright object mapping }\end{array}$ \\
\hline 8 - Panchromatic & 15.00 & $0.50-0.68$ & $\begin{array}{l}15 \text { meter resolution, sharper image } \\
\text { definition }\end{array}$ \\
\hline 9 - Band Cirrus & 30.00 & $1.36-1.38$ & $\begin{array}{l}\text { Improved detection of cirrus cloud } \\
\text { contamination }\end{array}$ \\
\hline 10 - TIRS 1 & 100.00 & 10.60-11.19 & $\begin{array}{l}100 \text { meter resolution, thermal } \\
\text { mapping and estimated soil moisture }\end{array}$ \\
\hline $11-$ TIRS 2 & 100.00 & $11.50-12.51$ & $\begin{array}{l}100 \text { meter resolution, improved } \\
\text { thermal mapping and estimated soil } \\
\text { moisture }\end{array}$ \\
\hline
\end{tabular}

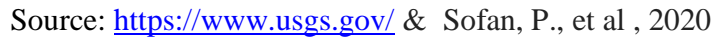

The applied of simple linear regression model between enhanced soil salinity index and electrical conductivity values of soil sampls has shown higher correlation than NDSI was 0.918 and determination coefficient (R2) was 0.783 . 


\section{Conclusion}

Outcomes of the current study indicate that there is a statistically significant relationship between the results of soil salinity indices and the field values of soil salinity. Soil salinity detection from satellite images is very significant for planning, monitoring, and management of salinity in the densely populated region because soil salinity is directly influencing the agriculture land use and livelihood patterns. Soil salinity changes appraisal in the geospatial environment using remote sensing techniques help to mitigate salinity hazard of developing and developed countries (Hassan, et al., 2021). In addition, the use of remote sensing techniques in monitoring and evaluating soil salinity is a rapid tool for large-scale detection by the authorities, which would enable the optimal economic exploitation of the sabkhas.

The sabkhas of the Wadi An-Natrun Depression's floor are an important source of the Natron salt in Egypt in abundant and renewable quantities, which Chemically composed of sodium compounds (Na2CO3, NaHCO3, Na2SO4, and NaCL2). These salts have an important economic return, especially for their proximity to the surface and the ease of mining, particularly in the summer. 
Determining the Effectiveness of Using Remote... Dr. Islam Saber Amin

\section{References:}

1- Aldabaa, A., Weindorf, D., Chakraborty, S., Sharma, A., \& $\mathrm{Li}$, B. (2015). Combination of proximal and remote sensing methods for rapid soil salinity quantification. Geoderma, 239, 34-46.

2- Ali, R., \& El Baroudy, A. (2008). Use of GIS in mapping the environmental sensitivity to desertification in Wadi El Natrun depression, Egypt. Australian Journal of Basic and Applied Sciences, 2(1), 157-164.

3- Allbed, A., \& Kumar, L. (2013). Soil salinity mapping and monitoring in arid and semi-arid regions using remote sensing technology: a review. Advances in remote sensing.

4- El-Fayoumy, I.F., 1964, Geology of Ground Water Supplies in Wadi EL-Natrun Area, M.Sc. Thesis, Fac. Sci., Cairo Unvi.

5- El Kashouty, M., \& El Sabbagh, A. (2011). Distribution and immobilization of heavy metals in Pliocene aquifer sediments in Wadi El Natrun depression, Western Desert. Arabian Journal of Geosciences, 4(5), 1019-1039.

6- El Osta, M., Hussein, H., \& Tomas, K. (2018). Numerical simulation of groundwater flow and vulnerability in Wadi ElNatrun depression and vicinities, west nile Delta, Egypt. Journal of the Geological Society of India, 92(2), 235247.

7- El-Shahat, A., Ayyad, S. N., \& Abdalla, M. A. (1997). Pliocene facies and fossil contents of Qaret El-Muluk formation at Wadi El-Natrun Depression, western desert, Egypt. Facies, 37(1), 211-224.

8- Gupta, K., Mukhopadhyay, A., Giri, S., Chanda, A., Majumdar, S. D., Samanta, S., \& Hazra, S. (2018). An index for discrimination of mangroves from non-mangroves using LANDSAT 8 OLI imagery. MethodsX, 5, 1129-1139.

9- Hassan, R., Ahmed, Z., Islam, M. T., Alam, R., \& Xie, Z. (2021). Soil Salinity Detection Using Salinity Indices from Landsat 8 Satellite Image at Rampal, Bangladesh. Remote Sensing in Earth Systems Sciences, 1-12. 
10- Moselhy, S. M., 2005, Groundwater Resources Management in Wadi El-Farigh and its Vicinities for Sustainable Agricultural Development, Ph. D., Thesis, Fac. Eng., Ain Shams Univ.

11- Sofan, P., Bruce, D., Jones, E., Khomarudin, M. R., \& Roswintiarti, O. (2020). Applying the Tropical Peatland Combustion Algorithm to Landsat-8 Operational Land Imager (OLI) and Sentinel-2 Multi Spectral Instrument (MSI) Imagery. Remote Sensing, 12(23), 3958.

12- Taher, A. G. (1999). Inland saline lakes of Wadi el Natrun depression, Egypt. International Journal of Salt Lake Research, 8(2), 149-169.

13- Wu, W. (2019). A Brief Review on Soil Salinity Mapping by Optical and Radar Remote Sensing. Research Developments in Saline Agriculture, 53-65.

14- Yahiaoui, I., Douaoui, A., Zhang, Q., \& Ziane, A. (2015). Soil salinity prediction in the Lower Cheliff plain (Algeria) based on remote sensing and topographic feature analysis. Journal of Arid Land, 7(6), 794-805.

15- Yousif, I. A. H. (2019). Integration of land cover changes and land capability of Wadi El-Natrun depression using vegetation indices. Egyptian Journal of Soil Science, 59(4), 385-402.

16- Zahran, M. A., \& Willis, A. J. (2008). The vegetation of Egypt, $2^{\text {nd }}$ ed. , Springer Science \& Business Media. 